BULLETIN OF PNRPU. GEOLOGY. OIL \& GAS ENGINEERING \& MINING

ВЕСТНИК ПНИПУ. ГЕОЛОГИЯ. НЕФТЕГАЗОВОЕ И ГОРНОЕ ДЕЛО

ISSN 2224-9923

Volume/ Tom 16 №1 2017

http://vestnik.pstu.ru/geo/

УДК 622.363.2:504

Article / Статья

(C) PNRPU / ПНИПУ, 2017

\title{
NEGATIVE IMPACT ON THE ENVIRONMENT CAUSED BY COMPANIES THAT MINE AND PROCESS POTASSIUM AND MAGNESIUM SALTS
}

\section{M.Yu. Liskova}

Perm National Research Polytechnic University (29 Komsomolskii av., Perm, 614990, Russian Federation)

\section{НЕГАТИВНОЕ ВОЗДЕЙСТВИЕ, ОКАЗЫВАЕМОЕ НА ОКРУЖАЮЩУЮ СРЕДУ ПРЕДПРИЯТИЯМИ ПО ДОБЫЧЕ И ОБОГАЩЕНИЮ КАЛИЙНО-МАГНИЕВЫХ СОЛЕЙ}

\section{М.Ю. Лискова}

Пермский национальный исследовательский политехнический университет (614990, Россия, г. Пермь, Комсомольский пр., 29)

Received / Получена: 11.08.2016. Accepted / Принята: 12.02.2017. Published / Опубликована: 31.03.2017

Key words:

pit, geoecology, salt piles, sludge storages, spoil heaps, solid wastes, mining industry, sludge, halite wastes, storage, rocks, reclamation, overburden rocks, enclosing rocks, standards.
Today mining is developing very intensively and potash industry in particular. Reserve areas are explored and cut, new fields are explored and developed, new license areas of potassium and magnesium deposits are developed. Underground mining of mineral deposits leads to significant deformation of the earth's surface. The impact of potash industry on the environment is diverse and covers many natural components. In case of mine flooding, catastrophic consequences, accompanied by depressions and sinkholes, cover a considerable area. The main feature of potash production is accumulation of a significant amount of waste in sludge storage and salt piles with brine collectors. Sewage and penetration from salt piles and sludge storage are the main sources of environmental pollution.

Mining and processing of ore at potash enterprises is associated with formation of a large number of waste rocks. Millions of tons of liquid and solid wastes are stored on ground surface in salt piles and brine sludge storages, which negatively affects the environment.

However, negative effects of salt pile placement can be avoided or minimized. Today there are a number of developments aimed to improve methods of underground storage of wastes of potash industry both solid halite and liquid clay-salt.

The paper considers a new version of waste disposal placement of potash industry, which is currently being considered in design documentation for development of licensed area of Nivenskoe-1 field of potassium and magnesium salts in Kaliningrad region. In case of a positive conclusion of state expertise, this technology will be implemented. Such approach could be used in development of other deposits of potassium and magnesium salts (Verkhnekamsk, Gremiachinsk etc.).

В настоящее время весьма интенсивно развивается горная промышленность, в частности калийная отрасль: доразведываются и прирезаются резервные участки, разведываются и осваиваются новые месторождения, разрабатываются новые лицензионные участки калийно-магниевых залежей. Подземная разработка месторождений полезных ископаемых приводит к значительным нарушениям земной поверхности. Воздействие калийной промышленности на окружающую среду разнообразно и охватывает многие природные компоненты. В случае затопления шахт катастрофические последствия, сопровождающиеся просадками и провалами, охватывают значительную территорию. Основной спецификой калийного производства является накопление значительного количества отходов в шламохранилищах и солеотвалах с рассолосборниками. Стоки и фильтрация из солеотвалов и шламохранилищ являются основными источниками загрязнения окружающей среды.

Добыча и переработка руды на калийных предприятиях связана с образованием большого количества породотходов. Миллионы тонн жидких и твердых отходов складируются на дневной поверхности в солеотвалы и рассолошламохранилища, что негативно влияет на окружающую среду.

Однако негативных последствий размещения солеотвалов можно избежать или минимизировать их. В настоящее время существует целый ряд разработок, направленных на совершенствование методов подземного складирования отходов калийной промышленности, как твердых галитовых, так и жидких глинисто-солевых.

В статье рассмотрен новый вариант размещения отходов калийной промышленности, который в данный момент закладывается в проектную документацию на освоение лицензионного участка Нивенское-1 месторождения калийно-магниевых солей в Калининградской области. В случае положительного заключения государственной экспертизы эта технология будет реализована. Данный подход мог бы быть использован при освоении и других месторождений калийно-магниевых солей (Верхнекамского, Гремячинского и др.).

Mariia Yu. Liskova (Author ID in Scopus: 55749420800) - PhD in technical sciences, Associate Professor at the Department of Life Safety (mob. tel.: +007 922 311 67 64, e-mail: liskova.rpb@gmail.com). 


\section{Introduction}

Today mining is developing very intensively and potash industry in particular. Reserve areas are explored and cut, new fields are explored and developed, new license areas of potassium and magnesium deposits are developed.

The largest reserves of potash deposits belong to Saskatchewan salt basin (Canada), potash deposits in Germany, Verkhnekamskoe field of potassium and magnesium salts (VKFPMS) (Russian Federation), Starobinskoe field of potassium salt (Republic of Belarus). These countries are the leaders among exporters of potash products and far ahead from other states [1]. Potash mines also exist in other countries, for example, in Uzbekistan (Dehkanabad Potash Plant Unitary Enterprise). In long term capacities of potash production can be expanded thanks to Gremiachinskoe, Nepskoe and Eltonskoe (Russian Federation), Petrikovskoe (Republic of Belarus), Garlykskoe (Turkmenistan) deposits [1].

One of the major potash deposits is in Perm region and called Verkhnekamskoe field of potash and magnesium salt. According to [2], 11 sites are explored in detail at this field. Four of them are located in a central part of deposits (Solikamskii, Novo-Solikamskii, Polovodovskii, Borovskii) and seven are located in southern (Bereznikovskii, Durymanskii, Balakhontsevskii, BygelskoTroitskii, Talitskii, Palasherskii, Ust-Iaiivinskii). Development of salt reserves of Verkhnekamskoe field is carried out by five mines such as SKRU-1 (Solikamskii and Novo-Solikamskii sites), SKRU2 (Solikamskii and Novo-Solikamskii sites), SKRU-3 (Novo-Solikamskii site), BKPRU-2 (Durymanskii site) and BKPRU-4 (BygelskoTroitskii site). Another four licenses were issued for exploration and production of potash and magnesium salts such as Ust-Iaiivinskii - Uralkali PJSC; Talitsky - Verkhnekamsk Potash Company CJSC (Akron), Palasherskii with a part of Balakhontsevskii site - Usolsky Potash Combine LLC (Evrokhim) and Polovodovskii - Kama Mining Company (Uralkali PJSC).

Underground mining of mineral deposits leads to significant violations of the earth's surface. In 1978 V.N. Mosinets and M.V. Griaznov showed negative impact of mining companies on a lot of components of geological environment. Change in the earth's crust occurs both during a process of mineral production and as a result of the processeffects [3]. Underground mining of mineral deposits is associated with formation of cracks, dips and deflections on the earth's surface, terrain swamping and formation of waste rock dumps [1].

\section{Impact of potash industry on the environment}

Impact of potash industry on the environment is diverse and covers many natural components [4, 5]. In case a mine is flooded, catastrophic consequences that are accompanied by subsidence and fall down, cover a significant territory [6]. The main feature of potash production is accumulation of a significant amount of waste in storages and salt piles with salt brine collectors. Wastes are represented by soluble components (potassium, sodium and magnesium chlorides) and contain a large amount of trace elements (strontium, manganese, nickel, cobalt, chromium, zinc etc.) and agents used to process minerals.

Today more than 270 million tons of halite waste (Fig.) and more than 30 million $\mathrm{m}^{3}$ of claysalt slurries have been accumulated on the territory of the VKFPS [7].

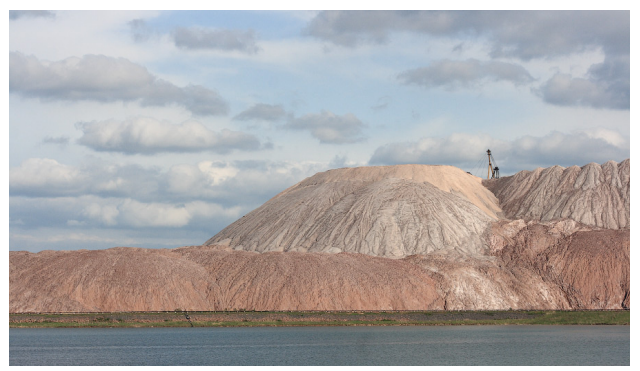

Fig. Salt pile on Verkhnekamskoe field of potash salt

Sewage and penetration from salt piles and sludge storages are the main sources of environmental pollution.

Mining and processing of ore at potash enterprises is associated with formation of a significant amount of waste rock. For example, for each ton of potassium chloride obtained during processing of sylvinite and carnallite ore there are 0.1-0.5 tons of clay-salt slurries and 3.5-4.5 tons (depending on extraction degree) of solid halite waste are formed at Verkhnekamskoe field of potash salt. Millions of tons of liquid and solid wastes generated annually at potash enterprises are 
stored on grond surface into salt piles and brinesludge storages respectively [8].

Allocation of salt piles and slurry storages on the surface has a negative impact on the environment:

1. A lot of ground resources are needed. The total area of salt piles and sludge storages is more than 1.000 hectares, and taking into account longterm development of potash production, they can extend up to 2-3 thousand hectares [9].

2. Piles and sludge contaminate hydrosphere. Industrial effluents into surface hydro network and penetration of brines into groundwater have led to formation of extensive halos of hydrosphere salinization, which threaten sources of domestic water supply. According to the data of [9], objects of pile and sludge industry BKRU-3 contaminate rivers Volim and Lenva. There is a halo of salinization of groundwater up to $2.5 \mathrm{~km}$ wide formed in the northern direction from a sludge storage. Industrial site and salt pile of BKPRU-4 form a saline halo with a length of about $1 \mathrm{~km}$ and a width of up to $1.5 \mathrm{~km}$, stretched in direction of a river Bygel, where a constant excess in concentration of chlorides is presented at all the time $(0.2-2.0 \mathrm{~g} / \mathrm{l})$.

3. Over the time, there are halos of salinization of soils, underground and surface water formed around storages of wastes of potash production. Their size and shape are largely determined by speed and direction of surface and underground runoff [10-12].

Widespread public opinion about the inevitability of such consequences of production activity of enterprises that extract and enrich potassium ores causes serious public concern, especially in areas where no new potassiummagnesium deposits were developed previously. Appearance of surface piles of empty rock and processing waste during development of Nivenskoe and the fact that people are concerned about the issue led to publication on the site [13] titled as "Great danger is knocking to our house!". Here is a small quote from the article: "There are preparatory works for development of potash salt deposits started just in 6 kilometers from Kaliningrad in village of Nivenskoe. Hundreds of thousands of tons of chemical waste produced during extraction and processing threaten the possible environmental disaster in our region" [13].
Nevertheless, it is possible to avoid negative consequences or minimized its amount. A number of developments is aimed to improve methods of underground storage of wastes from potash industry both solid halite and liquid clay salt $[14,15]$, as well as toxic wastes from other industries [16].

\section{Ways to store wastes from potash industry}

There are on-going works aimed to improve techniques to form heaps of potash production and reduce territories that are occupied by waste storage, joint storage of liquid and solid waste at one site [21-23]. Research Institute of Belgorkhimprom OJSC (Minsk, Belarus) established the possibility of using waste sludge as a base for expandable salt heaps, which allows significantly reducing area occupied by waste from potash production and reducing costs of formation of anti-penetration screen in to their base. A technology for joint storage of halite and sludge waste was developed by engineers. A technology allows excluding construction of sludge storages and reducing territory dedicated to tail industry. Content of clay sludges up to $25 \%$ during joint waste storage does not cause a significant change in overall strength of a mixture. In comparison with fresh clean halites it is even slighly higher.

There is a technology that regenetate used sludge storages was developed. A tecnology allow using built reservoirs for sludge waste storage multiple times. The most preferable in terms of use of sludge waste as a source of useful KCI product and microelements is the production of new forms of fertilizers and ameliorants that have been successfully tested in agriculture.

Implimentation of new technological schemes for waste storage at Republican Unitary Enterprise Production Association Belaruskali JSC, developed by Research Institute of Belgorkhimprom JSC and use of potash waste in national economy make it possible to reduce removal of fertile land for storage of waste of potash production by $30-40 \%$. Moreover, it decreases a volume of excess brines in the area of enrichment of potassium ore waste, thereby significantly reduces environmental risk in the Soligorsk mining area [24].

If enterprises for extraction and enrichment of potash ores are to be designed then among listed research and scientific developments, it is possible 
to develop technical solutions that allow disposing overburden and enclosing rocks almost completely during drilling of wells. It is possible to place empty (overburden and enclosing, including saline) rocks in used quarries of common spread minerals of building materials, peat productions and solid domestic waste landfills (SDWL) to restore economic value of disturbed land (reclamation) or creating such lands through landscape transformation of the terrain.

Currently, quarries for production of building materials are often located in urban area, on the outskirts of villages, which seriously affects their ecology. A lot of small quarries (several hundred) are in countryside. Almost every large vilage enterprise has a quarry of 1-10 hectares, where crushed stone, sand, clay, limestone are mined for local needs.

There is a large number of peat deposits and a large number of polygons on the territory of Russia that are overcrowded or whose life time has expired. These areas have a negative impact on components of environment, so their neutralization and return to a normative state are necessary. Moreover, today for recultivation both SDWL and quarries a large amount of natural soil is taken to make recultivation mixtures.

In order to assess the possibility of using overburden and enclosing rocks in reclamation of abandoned quarries by backfilling and planning of mines up to restoration of landscape as a whole, it is necessary to study suitability of samples of overburden and enclosing rocks, for example, during drilling of wells. Such studies are carried out by special organizations, for example, in the Analytical and Technological Certification Testing Center (ATCTC) of the Federal State Unitary Enterprise TsNIIgeolnerud and Research Laboratory MinAnalit, which are the basic laboratory centers of Rosnedra and have all the necessary certificates and licenses confirming their technical competence.

Such studies were conducted on the core of a control-bore well of cage shaft of Niven mine in Kaliningrad region. Based on the research it was determined that in accordance with the requirements of GOST 17.5.1.03-86 Conservation of Nature. Land. Classification of overburden and enclosing rocks for biological reclamation of land in terms of content of toxic salts almost all the studied rock samples are suitable and less suitable for overburden and enclosing rocks for biological reclamation of land and do not contain toxic compounds in concentrations dangerous to human life and the environment. The values of specific activity of natural radionuclides for all investigated samples of rocks do not exceed parameters for mineral raw materials stated in Norms of Radiation Safety (NRB-99/2009) and SanPiN 2.6.1.2523-09. Moreover, rocks that are less suitable for biological reclamation and contain easy to dissolve salts, gypsum, carbonates, can also be used for biological reclamation after improving the chemical properties of rocks or special agrotechnical actions, that could include dilution or mixing with overburden rocks of middle and upper sections of the structural (control-bore) well.

Certain points and requirements of regulations of Russian Federation should be highlighted, such as:

1) in accordance with Federal Classification of Waste Catalog (FCWC-2014), following codes and names were assigned to soils of overburden and enclosing rocks (in order No. 360 of the Federal Service for Supervision of Natural Resources and Environmental Protection dated April 28, 2015):

$\begin{array}{lllllll}-8 & 11 & 100 & 01 & 49 & 5 \text {. Soil, formed during }\end{array}$ excavation and not contaminated with hazardous substances.

-2 9210001205 . Overburden empty rock during drilling of mine borehole for extraction of potash salts.

-2 9210002205 . Overburden saline rock when drilling mine boreholes for extraction of potash salts, where the last Fig. (5) is V which represent a class of hazard for the environment which is almost non-hazardous.

2) In accordance with art. 18 of the Federal Law of 24.06.1998 No. 89-FZ On Production and Consumption Waste there are no overburden and enclosing rocks included to limits of waste disposal used in liquidation of mines in accordance with the project for their elimination;

3) In accordance with SanPiN 2.1.7.1322-03 Hygienic Requirements for Location and Disposal of Production and Consumption Wastes (approved by the Chief State Sanitary Doctor of Russian Federation on April 30, 2003) industrial wastes of IVth class of hazard, having a homogeneous structure with a size of fractions of less than $250 \mathrm{~mm}$, 
provided that the level of biochemical oxygen consumption (BOC 20) in the filtrate is kept at the level of 100-500 mg/l, chemical oxigen consumption not more than $300 \mathrm{mg} / \mathrm{l}$. Industrial waste allowed for joint storage with solid waste should meet following technological requirements: should not be explosive, self-ignitable and have moisture of not more than $85 \%$.

Thus, a comprehensive approach to overcome geoecological issues in the development of both operating and new fields, regulatory framework of Russian Federation and corresponding initiatives of reserve user, make it possible to use overburden and enclosing rocks from mine drilling in a complex of works on restoration of lands destroyed by industial activity in areas of open mining, common building materials, either on SDWL or in the process of landscape transformation of territories.

A specific case of an integrated approach to development of license area of the Nivenskii-1 field of potassium and magnesium salts in Kaliningrad region is full elimination of formation of humps of overburden and enclosing rocks during the drilling and construction of mine boreholes and in the long term from mining excavations, which is performed through the placement or disposal of these rocks:

1) in the base of construction sites of its own additional facilities, in particular: in excavations formed as a result of removal from the site of their construction of lacustrine-marsh sediments represented by peat and peat silt that can not serve as the basis for buildings and structures;

2) on SDWL of Kaliningrad region;

3) during recultivation of quarries of extraction of common spread mineral resources of building materials in Kaliningrad region;

4) for domestic purposes in the form of supplies of technical salt.

Subsequently, clay-salt sludges and halite waste generated during the enrichment and production of mineral fertilizers are sent to a mine in order to backfill worked-out space.

Such a complex approach used to find a solution that would reduce negative impact of production activities of mining and processing enterprises on natural objects and components of environment, habitats, flora and fauna, as well as excluding the distortion of aesthetic appearance of landscape surrounding areas could be implemented during development of Gremiachinskoe or Verkhnekamskoe fields of potassium salts. For example, there are 4 peat areas such as Verkhnekamskii, Priuralskii, Gorniy, Srednekamskii and Southern forest steppe only in the Perm region. The peat directory includes 874 deposits. Total peat balance includes 543 deposits.

\section{Conclusion}

Thus, the analysis of a complex of technical solutions in the field of environmentally safe development of deposits of potassium salts (in terms of operation of wastes in salt pits and slurry storages) shows that there are already a number of developments aimed to improve methods of underground storage of wastes from potash production that allow to reduce areas occupied by waste storages as well as methods of joint storage of liquid and solid waste on the same site. However, there is a technical solution described above that allows to entirely utilize overburden and enclosing rocks. This decision has already been considered in project documentation for development of the license area of Nivenskoe-1 deposit of potassium and magnesium salts in Kaliningrad region. In case of a positive conclusion of state expertise it will be implemented. This approach could be used in development of other deposits of potassium and magnesium salts such as Verkhnekamskoe, Gremiachinskoe and other fields.

\section{References}

1. Kologrivko A.A. Snizhenie geoekologicheskikh posledstvii pri podzemnoi razrabotke kaliinykh mestorozhdenii [Reduction of geoecological consequences for underground development of potash deposits]. Vestnik Polotskogo gosudarstvennogo universiteta, 2014, no.6, pp.103-110.

2. Solov'ev V.A., Sekuntsov A.I. Razrabotka kaliinykh mestorozhdenii [Development of potash deposits]. Perm', Izdatel'stvo Permskogo natsional'nogo issledovatel'skogo politekhnicheskogo universiteta, 2013, $265 \mathrm{p}$.
3. Gorbunov K.A., Maksimovich N.G., Andreichuk V.N. Tekhnogennoe vozdeistvie na geologicheskuiu sredu Permskoi oblasti [Technogenic impact on the geological environment of Perm region]. Perm', 1990, 44 p.

4. Bartl H., Doring G., Hartung K. et al. Kali im Südhars-Unstrur-Revier. Bochum, 2003, B. 1, 2, 2005. B. 3.

5. Liu J., Zhu J.-K. Proline accumulation and saltstress-induced gene expression in a salt-hypersensitive 
mutant of Arabidopsis. Plant Physiol, 1997, vol.114, pp.591-596. DOI: 10.1104/pp.114.2.591

6. Maksimovich N.G., Pervova M.S. Vliianie peretokov mineralizovannykh vod Verkhnekamskogo mestorozhdeniia kaliino-magnievykh solei na pripoverkhnostnuiu gidrosferu [Influence of flows of mineralized waters of Verkhnekamsk deposit of potassium-magnesium salts on the near-surface hydrosphere]. Inzhenernye izyskaniia, 2012, no.1, pp.22-28, available at: URL: http://nsi.psu.ru/labs/gtp/stat/2012/ 387.pdf (accessed 12 July 2016).

7. Bachurin V.A., Baboshko A.Iu. Ekologogeokhimicheskaia kharakteristika otkhodov kaliinogo proizvodstva [Ecological and geochemical characteristics of wastes of potash production]. Gornyi zhurnal, 2008, no.10, pp.88-91.

8. Komarov Iu.A. Obosnovanie tekhnologii vysotnogo skladirovaniia porod-otkhodov pri razrabotke kaliinykh mestorozhdenii [Substantiation of the technology of highlevel storage of rocks and wastes in the development of potash deposits]. Ph. D. thesis. Saint Petersburg, 2015, 152 p.

9. Boboshko A.Iu., Bachurin B.A. Ekologicheskie problemy verkhnekamskogo kaliia. Gornoe ekho, available at: http://ftp.mi-perm.ru/ge4-04/ge4-04-bach.htm (accessed 01 July 2016).

10.Lapinskaia V.O. Sposoby snizheniia zasoleniia zemel' $\mathrm{v}$ raionakh razrabotki kaliinykh mestorozhdenii [Methods of reducing the salinization of lands in the areas of development of potash deposits], available at: http:// science.kuzstu.ru/wp-content/Events/Conference/Other/2014/eko/ SE_2014/pages/Articles/Lapinskaya.pdf(accessed 01 July 2016).

11. Baturin E.N., Men'shikova E.A., Blinov S.M., Naumov D.Iu., Belkin P.A. Problemy osvoeniia krupneishikh kaliinykh mestorozhdenii mira [Problems of development of the largest potash deposits of the world]. Sovremennye problemy nauki i obrazovaniia, 2012, no.6, available at: https://www.science-education.ru/ru/article/ view?id=7513 (accessed 01 July 2016).

12. Koca M., Bor M., Ozdemir F., Turkan I. The effect of salt stress on lipid peroxidation, antioxidative enzymes and proline content of seasame cultivars. Environmental and Experimental Botany, 2007, vol.60, iss.3, pp.344-351. DOI: 10.1016/j.envexpbot.2006.12.005

13. Problema «V nash dom stuchitsia bol'shaia opasnost"!» [The problem "There is a great danger knocking in our door!"], available at: http://www.rezonans39.ru/?menu=problem. (accessed 01 July 2016).

14. Nesterov M.P., Borzakovskii B.A. et al. Sposob podgotovki kamer dlia podzemnogo skladirovaniia soleshlamovykh otkhodov [Method for preparing chambers for underground storage of salt-scrap waste]. Pat. Rossiiskaia Federatsiia no.2166096, 2001.

15. Nikoforov V.N., Kuznetsov Iu.S. et al. Sposob podzemnogo skladirovaniia zhidkikh otkhodov proizvodstv [The method of underground storage of liquid waste products]. Pat. Rossiiskaia Federatsiia no.2128140, 1999.

16. Marakov V.E., Nesterov M.P. et al. Sposob sozdaniia podzemnykh khranilishch toksichnykh otkhodov $\mathrm{v}$ solenosnykh porodakh [Method for the creation of underground storage of toxic waste in saliferous rocks]. Pat. Rossiiskaia Federatsiia no.2066770, 1996.

17. Berezin A.L., Borzakovskii B.A. et al. Sposob otvaloobrazovaniia otkhodov obogashcheniia kaliinykh rud na slaboe osnovanie [The method for depositing wastes of enrichment of potash ores on a weak base]. Pat. Rossiiskaia Federatsiia no.2204717, 2003.

18. Iurchenko O.L., Makhliankin I.B. et al. Sposob otvaloobrazovaniia otkhodov kaliinogo proizvodstva [Method of waste management of potash waste]. Pat. SSSR no.1677319, 1991.

19. Krainev B.A., D'iakov S.P., Shumakher A.I., Belkin V.V. Sposob likvidatsii soleotvalov na kaliinykh rudnikakh [The method of eliminating salt mines in potash mines]. Pat. Rossiiskaia Federatsiia no.2355887, 2009.

20. Phinney R. Formulation of potassum sulfate, sodium carbonate and sodium bicarbonate from potash brine. Patent WO 01/28925 A1, 26.04.2001.

21. Borzakovskii B.A., Grinberg A.Ia. et al. Sposob razmeshcheniia otkhodov obogatitel'nykh fabrik kaliinykh kombinatov [Method of disposal of waste from concentrating plants of potash plants]. Pat. Rossiiskaia Federatsiia no.2402682, 2010.

22. Borzakovskii B.A., Kon'shin A.A. et al. Sposob razmeshcheniia soleotvala $\mathrm{i}$ shlamokhranilishcha na odnoi ploshchadke [A method for placing a salt reservoir and a sludge storage facility at one site]. Pat. Rossiiskaia Federatsiia no.2316651, 2008.

23. Singewald A., Fricke G., Geisler I. Verfahren zur gewinnung von wertsoffen aus kieseritischen kalirohsalzen. Patentschrift DD 283956 A5, 31.10.1990.

24. Shishkova I.I. Geoekologicheskie problemy osvoeniia Starobinskogo mestorozhdeniia kaliinykh solei [Geoecological problems of development of the Starobinsky deposit of potassium salts], available at: http://www.lib.tpu.ru/bulltext/c/2012/c11/V2/299.pdf (accessed 01 July 2016).

\section{Библиографический список}

1. Кологривко А.А. Снижение геоэкологических последствий при подземной разработке калийных месторождений // Вестник Полоцкого государственного университета. - 2014. - № 16. - С. 103-110.

2. Соловьев В.А., Секунцов А.И. Разработка калийных месторождений: практикум. - Пермь: Издво Перм. нац. исслед. политехн. ун-та, 2013. - 265 с.
3. Горбунов К.А., Максимович Н.Г., Андрейчук В.Н. Техногенное воздействие на геологическую среду Пермской области. - Пермь, 1990. - 44 с.

4. Bartl H., Doring G., Hartung K. et al. Kali im SüdharsUnstrur-Revier. - Bochum, 2003. - B. 1, 2. - 2005. B. 3.

5. Liu J., Zhu J.-K. Proline accumulation and saltstress-induced gene expression in a salt-hypersensitive 
mutant of arabidopsis // Plant Physiol. - 1997. Vol. 114. - P. 591-596. DOI: 10.1104/pp.114.2.591.

6. Максимович Н.Г., Первова М.С. Влияние перетоков минерализованных вод Верхнекамского месторождения калийно-магниевых солей на приповерхностную гидросферу [Электронный ресурс] // Инженерные изыскания. - 2012. - № 1. - C. 22-28. URL: http:// nsi.psu.ru/labs/ gtp/stat/2012/387.pdf. (дата обращения: 12.07.2016).

7. Бачурин В.А., Бабошко А.Ю. Эколого-геохимическая характеристика отходов калийного производства // Горный журнал. - 2008. - № 10. - С. 88-91.

8. Комаров Ю.А. Обоснование технологии высотного складирования пород-отходов при разработке калийных месторождений: дис. ... канд. техн. наук. - СПб., 2015. - 152 с.

9. Бобошко А.Ю., Бачурин Б.А. Экологические проблемы верхнекамского калия [Электронный pecypc] // Горное эхо. - URL: http://ftp.mi-perm.ru/ge404/ge4-04-bach.htm (дата обращения: 01.07.2016).

10. Лапинская В. О. Способы снижения засоления земель в районах разработки калийных месторождений [Электронный ресурc]. - URL: http://science.kuzstu.ru/wpcontent/Events/Conference/Other/2014/eko/SE_2014/pages/ Articles/Lapinskaya.pdf (дата обращения: 01.07.2016).

11. Проблемы освоения крупнейших калийных месторождений мира [Электронный ресурс] / Е.Н. Батурин, Е.А. Меньшикова, С.М. Блинов, Д.Ю. Наумов, П.А. Белкин // Современные проблемы науки и образования. - 2012. - № 6. - URL: https://www.science-education.ru/ru/article/view?id=7513 (дата обращения: 01.07.2016).

12. The effect of salt stress on lipid peroxidation, antioxidative enzymes and proline content of seasame cultivars / M. Koca, M. Bor, F. Ozdemir, I. Turkan // Environmental and Experimental Botany. - 2007. - Vol. 60, iss. 3. - P. 344-351. DOI: 10.1016/j.envexpbot.2006.12.005

13. Проблема «В наш дом стучится большая опасность!» [Электронный ресурс]. - URL: http:// www.rezonans39.ru/?menu=problem (дата обращения: 01.07.2016).
14. Способ подготовки камер для подземного складирования солешламовых отходов: пат. Рос. Федерация № 2166096 / Нестеров М.П., Борзаковский Б.А. и др.; 27.06.2001.

15. Способ подземного складирования жидких отходов производств: пат. Рос. Федерация № 2128140 / Никофоров В.Н., Кузнецов Ю.С. и др.; 27.03.1999.

16. Способ создания подземных хранилищ токсичных отходов в соленосных породах: пат. Рос. Федерация № 2066770 / Мараков В.Е., Нестеров М.П. и др.; 20.09.1996.

17. Способ отвалообразования отходов обогащения калийных руд на слабое основание: пат. Рос. Федерация № 2204717 / Березин А.Л., Борзаковский Б.А. и др.; 20.05.2003.

18. Способ отвалообразования отходов калийного производства: пат. СССР № 1677319 / Юрченко О.Л., Махлянкин И.Б. и др.; 15.09.1991.

19. Способ ликвидации солеотвалов на калийных рудниках: пат. Рос. Федерация № 2355887 / Крайнев Б.А., Дьяков С.П., Шумахер А.И., Белкин В.В.; 20.05.2009. - Бюл. № 14.

20. Formulation of potassum sulfate, sodium carbonate and sodium bicarbonate from potash brine: pat. WO 01/28925 A1 / Phinney R.; 26.04.2001.

21. Способ размещения отходов обогатительных фабрик калийных комбинатов: пат. Рос. Федерация № 2402682 / Борзаковский Б.А., Гринберг А.Я. и др.; 27.10.2010.

22. Способ размещения солеотвала и шламохранилища на одной площадке: пат. Рос. Федерация № 2316651 / Борзаковский Б.А., Коньшин А.А. и др.; 10.02.2008

23. Verfahren zur gewinnung von wertsoffen aus kieseritischen kalirohsalzen. Patentschrift DD 283956 A5 / Singewald A., Fricke G., Geisler I.; 31.10.1990.

24. Шишкова И.И. Геоэкологические проблемы освоения Старобинского месторождения калийных солей [Электронный pecypc]. - URL: http://www.lib.tpu.ru/bulltext/c/2012/c11/V2/299.pdf (дата обращения: 01.07.2016).

Please cite this article in English as:

Liskova M.Yu. Negative impact on the environment caused by companies that mine and process potassium and magnesium salts. Bulletin of PNRPU. Geology. Oil \& Gas Engineering \& Mining, 2017, vol.16, no.1, pp.82-88. DOI: 10.15593/2224-9923/2017.1.9

Просьба ссылаться на эту статью в русскоязычных источниках следующим образом:

Лискова М.Ю. Негативное воздействие, оказываемое на окружающую среду предприятиями по добыче и обогащению калийно-магниевых солей // Вестник Пермского национального исследовательского политехнического университета. Геология. Нефтегазовое и горное дело. - 2017. - Т.16, №1. - C.82-88. DOI: 10.15593/2224-9923/2017.1.9 